\title{
Evaluation For the Recovery Environmental the Beach Chorrillos of Huacho
}

\author{
Napoleón JAUREGUI NONGRADOS \\ Universidad Privada del Norte, Lima, Perú \\ napoleon.jauregui@upn.pe
}

Received date: 5 April 2021; Accepted date: 29 August 2021; Published date: 17 December 2021

Academic Editor: Andrés Edgardo Pardo Labrín

Copyright (C) 2021. Napoleón JAUREGUI NONGRADOS. Distributed under Creative Commons Attribution 4.0 International CC-BY 4.0

\begin{abstract}
The Chorrillos beach of the port of Huacho, is located north of Lima, Peru, and is contaminated by wastewater and solids, discharges by industry and population. For your evaluation of recovery environmental experimental research was applied using the following techniques: observation, environmental assessment, surveys, measurement of effluent flows and analysis of samples of its marine waters. The surveys were processed using SPSS statistical software, to measure frequency of respondent's age and sex, the percentage of acceptance of salubrity, environmental awareness, identification with the port and solution to pollution. The results show that $100 \%$ of the population contributes to pollution, because of a lack of environmental education and because the competent authority does not control or sanction. Likewise, the most important results of the samples taken at 50, 250 and $500 \mathrm{~m}$ from these marine waters were: total and thermotolerant coliforms ( $<1 \mathrm{Ufc}$ ), dissolved oxygen (5.4, 3.0 and $4.5 \mathrm{mg} / \mathrm{L}$ ), biochemical oxygen demand $(13.9,13.4$ and $18.3 \mathrm{mg} / \mathrm{L})$, oils and fats $(148,159$ and $136 \mathrm{mg} / \mathrm{L})$ and lead in average of $0.06 \mathrm{mg}$. $\mathrm{L}^{-1}$. These results indicate that this beach is polluted, compared to the standards of both Peru and the WHO, PAHO and APM of the USA, whose measurement of impacts show high significance, more its environmental assessment demonstrates that it is possible to recover it for the benefit of the sustainable development of the port of Huacho; recommending to the competent authorities for its immediate sustainability, otherwise it will be a harmful environment for humanity.
\end{abstract}

Keywords: Beach, pollution, sustainable development, environmental remediation.

\section{Introduction}

The port of Huacho is located $180 \mathrm{~km}$ north from Lima, Peru, this port is the beach "Chorrillos of Huacho", where the population disposes of their waste illegally, causing contamination; product of this, is affecting the quality of this beach, the species that inhabit it and the health of the people. For this reason, many marine

Cite this Article as: Napoleón JAUREGUI NONGRADOS (2021)," Evaluation For the Recovery Environmental the Beach Chorrillos of Huacho" International Journal of Renewable Energy and Biofuels, Vol. 2021 (2021), Article ID 630428, DOI: 10.5171/2021.630428 
species such as lifeless birds can be observed on the shore of the beach. This is to be expected because in its marine waters end up the effluents of industrial wastewater, municipal and agricultural drainage, all untreated, whose problem is aggravated because there are no environmental policies by the local and regional government, requiring the treatment of these waters, which favors the continuation of pollution in this geographical space. As a result, these marine waters are changing their physical, chemical and biological properties as a result of contamination, so that upon simple observation one can see denaturedcolored waters with solid waste floating in them. Also, excreta is observed along the beach of this port, which shows strong fecal contamination, and there is also a large amount of solid waste scattered on its banks, especially clearing; therefore, the beach Chorrillos of Huacho is closed by municipal ordinance for any activity, which lacks compliance because there is no control by the competent authority; for this reason, the following question is asked. How can evaluated for environmental recovery of beach Chorrillos of Huacho?

The contamination of these coastal waters has also been evaluated by other researchers from the point of view of physical-chemical and biological analysis. Orozco et al. (1995) demonstrated that the ecosystems of the bay of the port of Huacho support a pollution load above the maximum permissible limits. In addition, the effects of pollution in this bay were studied by Sánchez et al. (1996), who demonstrated that the macrozoobenthos has disappeared from its natural habitat, and the results of this work are reaffirmed by Evangelista (2002), who demonstrates that pollution persists in Huacho Bay, especially in its port, Even the General Directorate of Environmental Health (1999) in coordination with the Provincial Municipality of Huaura-Huacho, to date, has closed Chorrillos beach, which is adjacent to the port, because it was found to have limits of thermotolerant coliforms that exceed the norms and also because its sand is of very poor quality, with solid waste all over the beach. Despite these facts, there are no environmental impact studies that demonstrate the real environmental damage of these coastal waters. For this reason, the present research work aims to evaluate the beach Chorrillos of Huacho for its environmental recovery, which has identified the causes of pollution, measuring the degree of pollution and impacts of components such as physical, chemical, biological and socioeconomic. Although there was a limitation in measuring the flows of the agricultural drain, which passes through the fishing factories, where the corresponding permit was not obtained, this has not prevented the measurement of the flows that end up on the beach.

The present investigation is justified since it allows to us know the intensity of the environmental damage and the risks to which the huachana population is exposed because it demonstrates the contamination and the impacts produced in the coastal waters of the port of Huacho that correspond to its beach. This is a starting point to take actions for remediation and environmental recovery of this beach, contributing to the sustainable development of the Port of Huacho so that present and future generations can meet their own needs in it and, at the same time, is a tool that serves to assess and recover other polluted beaches. From the evaluation performed, it is demonstrated that the beach Chorrillos of Huacho is environmentally recoverable, which is an indicator to be taken into account by the competent authorities, so that in their functions they should apply responsible environmental management, as soon as possible, not only for its environmental recovery but also for its sustainability, which would be a point of development for its population, since this beach has many potential resources that would easily turn it into a very attractive seaside resort for tourism.

\section{Materials and Methods}

\section{Surveys}

Surveys were prepared for application to the population of the port of Huacho, after 
random sampling. Thirty-four questions were prepared, including open-ended $(\mathrm{n}=$ $6)$, closed-ended $(n=25)$ and hierarchical ( $\mathrm{n}=3$ ) questions. The survey was conducted on April 16, 2005. The survey was conducted on April 16, 2005, for a household analysis, applying the questions to the head of household.

For the processing of the survey, the statistical program SPSS version 12 was applied to measure the frequency of the age and sex of the respondents, the percentage of acceptance on sanitary conditions of the port of Huacho, environmental awareness of the population, identification with the port and solution to the port pollution.

\section{Population and sample}

The population of the port area of Huacho, according to the municipal cadastre of this city (2005), is occupied by 246 dwellings, with a population index of 5 inhabitants per dwelling. Based on the mathematical models of Collazos (2004). The sample consisted of 140 dwellings.

\section{Marine water quality}

The observational and analytical method was applied, for which samples were taken offshore beach Chorrillos of Huacho to the sea outside the at distances of $50 \mathrm{~m}, 250 \mathrm{~m}$, $500 \mathrm{~m}$, respectively. For the analysis of these samples, the services of the Laboratory "Minerals of laboratories S.R.L", located in Callao, Peru, were contracted, who used the methodology shown in Table 1.

Table 1: methodology used by Laboratory “Minerals of laboratories S.R.L.-Minlab”

\begin{tabular}{|l|l|}
\hline Determination & Methodology \\
\hline Cyanide Watt & $\begin{array}{l}\text { SMEWW APHA AWWA WEF. 20thEdition. 1999. Part 4500-CN B. } \\
\text { Colorimeter Method }\end{array}$ \\
\hline Total Cyanide & $\begin{array}{l}\text { SMEWW APHA AWWA WEF. 20thEdition. 1999. Part 4500-CN B. } \\
\text { Colorimeter Method }\end{array}$ \\
\hline Cadmium & $\begin{array}{l}\text { SMEWW APHA AWWA WEF. 20thEdition. 1999. Part 3111B. Metals by } \\
\text { Flame Atomic Absorption Spectrometry. Direct Air Acetylene Flame } \\
\text { Method }\end{array}$ \\
\hline Lead & $\begin{array}{l}\text { SMEWW APHA AWWA WEF. 20thEdition. 1999. Part 3111B. Metals by } \\
\text { Flame Atomic Absorption Spectrometry. Direct Air Acetylene Flame } \\
\text { Method }\end{array}$ \\
\hline Zinc & $\begin{array}{l}\text { SMEWW APHA AWWA WEF. 20thEdition. 1999. Part 3111B. Metals by } \\
\text { Flame Atomic Absorption Spectrometry. Direct Air Acetylene Flame } \\
\text { Method }\end{array}$ \\
\hline Iron & $\begin{array}{l}\text { SMEWW APHA AWWA WEF. 20thEdition. 1999. Part 3111B. Metals by } \\
\text { Method Atomic Absorption Spectrometry. Direct Air Acetylene Flame }\end{array}$ \\
\hline Arsenic & $\begin{array}{l}\text { SMEWW APHA AWWA WEF. 20thEdition. 1999. Part 3111B. Metals by } \\
\text { Flame Atomic Absorption Spectrometry. Direct Air Acetylene Flame } \\
\text { Method }\end{array}$ \\
\hline Magnesio & $\begin{array}{l}\text { SMEWW APHA AWWA WEF. 20thEdition. 1999. Part 3111B. Metals by } \\
\text { Flame Atomic Absorption Spectrometry. Direct Air Acetylene Flame } \\
\text { Method }\end{array}$ \\
\hline Magnesium & $\begin{array}{l}\text { SMEWW APHA AWWA WEF. 20thEdition. 1999. Part 3111B. Metals by } \\
\text { Flame Atomic Absorption Spectrometry. Direct Air Acetylene Flame } \\
\text { Method }\end{array}$ \\
\hline Nickel & $\begin{array}{l}\text { SMEWW APHA AWWA WEF. 20thEdition. 1999. Part 3111B. Metals by } \\
\text { Flame Atomic Absorption Spectrometry. Direct Air Acetylene Flame } \\
\text { Method }\end{array}$ \\
\hline EPA 1664 Approved for NPDES (revision to page 1-23) \\
\hline
\end{tabular}

Napoleón JAUREGUI NONGRADOS, International Journal of Renewable Energy \& Biofuels, DOI: $10.5171 / 2021.630428$ 


\begin{tabular}{|l|l|}
\hline greases & \\
\hline Chlorides & EPA 325.3 Approved for NPDES (revised editorial 1982) \\
\hline Total Alkalinity & SM 2320-B Ed 20 th, page 2-27 \\
\hline Total Hardness & EPA 215.2 Approved for NPDES (revised editorial 1978) \\
\hline $\begin{array}{l}\text { Dissolved } \\
\text { oxygen }\end{array}$ & EPA 360.2 Approved for NPDES (revised editorial 1978) \\
\hline pH & EPA 150.1 (revised editorial 1978) \\
\hline Temperature & EPA 170.1 Approved for NPDES (revised editorial 1974) \\
\hline TSS & EPA 160.3 Approved for NPDES (issued 1971) \\
\hline Nitrates & EPA 354.1 Approved for NPDES (issued 1971) \\
\hline
\end{tabular}

The results of these samples were evaluated according to the General Water Law, for Class IV in Peru and also in comparison to WHO, PAHO, APM standards in the USA.

\section{Measurement of effluent flow rates}

This was done according to the principles of fluid mechanics, specifically for open flumes, based on the models of Potter and Wiggert (1997), from which the determination of the flow rate was applied:

$$
Q=4 B H^{1.522 B^{0.026}}
$$

In this case:

$\mathrm{Q}=$ Flow rate in cubic feet.

$\mathrm{B}=$ Channel width of least constriction in feet.

$\mathrm{H}=$ Upstream channel depth in feet.

\section{Measurement and evaluation of} environmental impacts

There are numerous methods for the identification of impacts. For this research, the technique called Check List (Conesa, 1997) has been used; it consists in the elaboration of a list of potential impacts, grouping them by environmental aspects. The measurement of environmental impacts is qualified based on the following criteria:

Type: Indicates whether the impact is adverse or Negative (-) or beneficial or Positive (+).

Intensity: It qualifies the force of action of the impact on the environmental factor, this is qualified as Low, Medium, High.
Persistence: It is qualified as Fleeting when it is of low action, Temporary when it is of moderate action, Permanent if it is of high action.

Recoverability: Refers to the capacity of the system to recover its original environmental conditions and is qualified as Reversible, Recoverable and Irrecoverable.

Effects: Indicates the interrelationships of actions, qualified as Simple, Cumulative, Synergistic.

Extent: It is directly related to the affected surface, qualified as Punctual, Partial and Total.

For the Environmental Impact Assessment, the cause-effect matrix method was applied, taken from Conesa F. (1997) and Canter L. (1998), which is one of the most widely accepted methods for Environmental Impact Assessment. This method of identification and evaluation can be adjusted to the different phases of a project, generating quali-quantitative results, and allows the analysis of the causal relationships between a given action and its possible effects on the environment.

This method is the most appropriate for identifying and assessing direct impacts. They also help to define the qualitative or quantitative interrelations of the activities and actions of the project with the environmental indicators and can also be used to systematize other types of information, such as locating in space and time the preventive or corrective measures 
and associating them with those responsible for their implementation.

For the cause-effect methodology, the identification, measurement or valuation of environmental impacts are given in the following way:
- Character (Ca): This refers to whether the impact is beneficial $(+)$ or detrimental (-).

- Probability of occurrence (Pro): It is valued with an arbitrary scale:

$\begin{array}{llll}\text { Very Unlikely } & 0.10 & - & 0.20 \\ \text { Unlikely } & 0.21 & - & 0.40 \\ \text { Probable or possible } & 0.41 & - & 0.60 \\ \text { Very likely } & 0.61 & - & 0.80 \\ \text { Certain } & 0.81 & - & 1.00\end{array}$

- Magnitude (Mg): The magnitude of the impacts will be evaluated based on a set of technical criteria, characteristics and qualities, which are as follows:

$\begin{array}{ll}\text { Low } & \mathbf{0} \\ \text { Medium } & \mathbf{1} \\ \text { High } & \mathbf{2}\end{array}$

b) Persistence (P): To be evaluated with a scale of:

$\begin{array}{ll}\text { Fleeting } & \mathbf{0} \\ \text { Temporary } & \mathbf{1} \\ \text { Permanent } & \mathbf{2}\end{array}$

c) Recoverability (R): To be assessed on a scale of:

$\begin{array}{ll}\text { Reversible } & \mathbf{0} \\ \text { Recoverable } & \mathbf{1} \\ \text { Unrecoverable } & \mathbf{2}\end{array}$

d) Effects (E): To be assessed on a scale of:

$\begin{array}{ll}\text { Simple } & \mathbf{0} \\ \text { Cumulative } & \mathbf{1} \\ \text { Synergistic } & \mathbf{2}\end{array}$

e) Extension (Ex): To be assessed on a scale of:

$\begin{array}{ll}\text { Punctual } & \mathbf{0} \\ \text { Partial } & \mathbf{1} \\ \text { Total } & \mathbf{2}\end{array}$

- Importance (Im): It will be evaluated with a scale that takes into account the importance of the impact related to the environmental value of each component that is affected by the polluting sources, whose scale is as follows:
1-3: Environmental component with low baseline quality, not relevant to other components.

4-5: Component has high basal quality, but is not relevant to other components.

6-7: Component has low basal quality, but is relevant to other components. 
8-10: Environmental component is relevant or of primary importance to other environmental components.

Total impact was calculated by multiplying Character (Ca), Probability (Pro), Magnitude (Mg) and Importance

- Not significant

- Slightly significant

- Moderately significant

- Significant

- Highly significant
(Im). Magnitude as the sum of Intensity (I), Persistence (P), Recoverability (R), Effects (E) and Extent (Ex), whose model is shown:

Total Impact $=$ Ca $\mathrm{x}$ Pro $\mathrm{x}$ Mg $\mathrm{x}$ Im

Impacts were rated as:

$$
\begin{gathered}
0-20 \\
21-40 \\
41-60 \\
61-80 \\
81-100
\end{gathered}
$$

The "Total Impact" assessment for each identified impact should refer to the physical-chemical, biological, socioeconomic and human or cultural environments.

\section{Result}

Surveys

The results of the survey are presented in the following figure and tables:

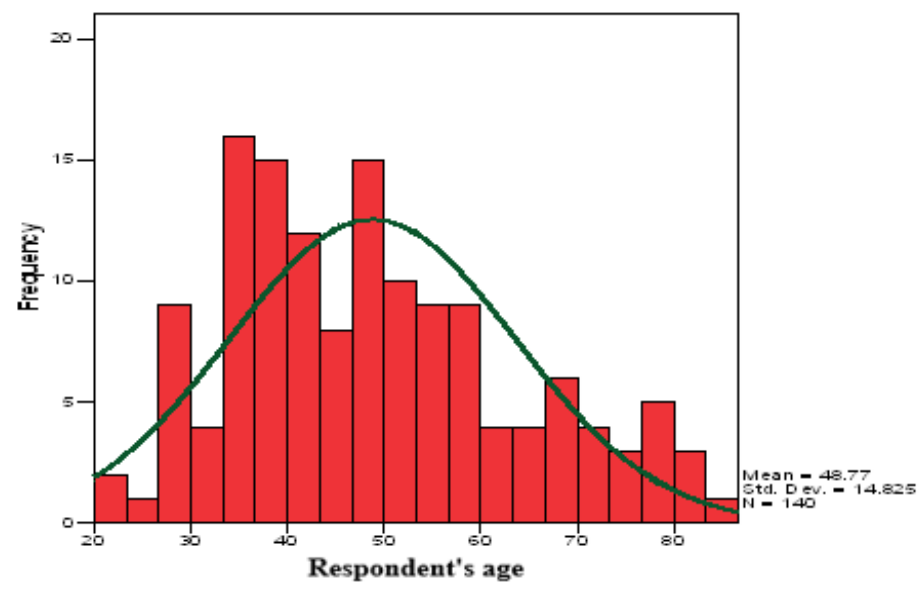

Fig. 1. Frequency of respondents' ages. 
Table 2: sex of respondent

\begin{tabular}{|l|l|l|l|}
\hline Sex & Frequency & Percentage & Percentage Cumulative \\
\hline Male & 96 & 68.6 & 68.6 \\
\hline Female & 44 & 31.4 & 100 \\
\hline Total & 140 & 100.0 & \\
\hline
\end{tabular}

Table 3: sanitary conditions of the port of Huacho

\begin{tabular}{|l|l|l|}
\hline $\mathbf{N}^{\circ}$ & Conditions & \% Acceptance \\
\hline 1. & Municipal garbage collection service only once a day. & 100,0 \\
\hline 2. & They have water and a drain. & 82,9 \\
\hline 3. & Eliminate excreta & \\
& In latrines. & 3,6 \\
& Into the gully. & 7,9 \\
& To the agricultural drain. & 5,7 \\
& Drainage. & 82,9 \\
\hline 4. & Fate of the garbage: & \\
& Burning. & 4,3 \\
& $\begin{array}{l}\text { Dumps it in the ravine. } \\
\text { Delivery to the municipal truck. }\end{array}$ & 22,9 \\
\hline 5. & Dumps it in the street. & 61,4 \\
\hline 6. & Reason for throwing garbage into the ravine: & 11,4 \\
\hline & It's a dump. & 55,7 \\
& There is nowhere to leave it. & 66,4 \\
& Sometimes the municipal truck doesn't pass. & 20,1 \\
\hline 7. & It bothers the house. & 9,0 \\
\hline 8. & He sees garbage thrown into the ravine. & 4,5 \\
\hline 9. & It is affected by the proliferation of rodents and insects. & 64,3 \\
\hline 10. & The marine waters of the harbor caused him health & 37,1 \\
\hline 11. & Frequently finds dead marine species on the shore. & 39,3 \\
\hline 12. & There is health control of the port's marine waters. & 0,0 \\
\hline
\end{tabular}

Table 4: environmental awareness of the population

\begin{tabular}{|l|l|}
\hline Enunciado & \% Aceptación \\
\hline Some institution informed you that garbage is recycled. & 0,0 \\
\hline The town uses the Atalaya hill as a waste dump due to: & \\
Lack of education. & 15,7 \\
Indifference. & 3,6 \\
Lack of control. & 3,6 \\
All of the above. & 77,1 \\
\hline It agrees to wash the fishermen's products directly in & 85,0 \\
the marine waters of the port. & \\
\hline Marine waters of the port are polluted & 100,0 \\
\hline The cause of port pollution is due to: & 8,6 \\
Vessels & 1,4 \\
Agricultural drainage & 5,7 \\
The drains &
\end{tabular}

Napoleón JAUREGUI NONGRADOS, International Journal of Renewable Energy \& Biofuels, 


\begin{tabular}{|l|l|}
\hline Factories & 7,9 \\
All & 76,4 \\
\hline Major pollutant of marine waters: & \\
Factories & 61,4 \\
Agricultural drainage & 3,6 \\
Sewage outfalls & 21,4 \\
Ships & 13,6 \\
\hline Guilty of port pollution: & \\
The people & 4,3 \\
The municipality & 47,1 \\
Port Captaincy & 2,9 \\
Regional Government & 1,4 \\
Central Government & 9,3 \\
The industry & 18,6 \\
All of them. & 16,4 \\
\hline
\end{tabular}

Table 5: identification with the port

\begin{tabular}{|l|l|}
\hline Statement & \% Acceptance \\
\hline He likes the port & 87,9 \\
\hline State that the port has known: & \\
Best & 50,0 \\
Equal & 50,0 \\
Worst & 0,0 \\
\hline There is fishing activity in the & 10,7 \\
port. & \\
\hline Works in fishing & 85,7 \\
\hline Why don't you fish in this port? & \\
It is polluted & 0,6 \\
It is not allowed & 11,1 \\
There is little marine resource & 88,3 \\
\hline How do you use the port? & \\
Fishing. & 5,7 \\
Swimming. & 5,7 \\
Sport on the sand. & 12,1 \\
Walking. & 12,1 \\
You don't use it. & 64,3 \\
\hline The port of Huacho is a tourist & 92,1 \\
resource for you. & \\
\hline What value do you place on the & \\
port of Huacho? & 0,7 \\
Good & 12,9 \\
Regular & 60,0 \\
Bad & 26,4 \\
\hline Very bad & \\
\hline
\end{tabular}

Napoleón JAUREGUI NONGRADOS, International Journal of Renewable Energy \& Biofuels, 
Table 6: solution to port contamination

\begin{tabular}{|l|l|}
\hline Statement & \% Acceptance \\
\hline $\begin{array}{l}\text { Eradicate the port industry: } \\
\text { Agree. }\end{array}$ & 49,3 \\
$\begin{array}{l}\text { Disagree } \\
\text { Indifferent }\end{array}$ & 41,4 \\
\hline $\begin{array}{l}\text { They are not organized to prevent contamination of these } \\
\text { waters. }\end{array}$ & 100,0 \\
\hline $\begin{array}{l}\text { It is willing to participate in the environmental recovery of } \\
\text { these marine waters. }\end{array}$ & 100,0 \\
\hline He is willing to pay for the improvement of the port waters. & 12,9 \\
\hline $\begin{array}{l}\text { He has planned to protest to prevent the destruction of the } \\
\text { port's landscape. }\end{array}$ & 45,0 \\
\hline
\end{tabular}

\section{Pollutants}

From the surveys and observation, it is clear that the pollutants in the port of Huacho are: wastewater from the INDUMAR, CREVOISIER and SICA fishing factories, as well as an agricultural drain and the domestic sewage collector of the EMAPA Company, which belongs to the Provincial Municipality of Huaura-Huacho. Also included are the ballast from fishing vessels anchored in this port and the people for disposing of their solid waste in these coastal waters.

\section{Laboratory Results}

The results of the samples taken on December 16, 2004, to the sea outside at distances of $500 \mathrm{~m} 500 \mathrm{~m}$ (P-1), $250 \mathrm{~m}$ (P2) and $50 \mathrm{~m} \mathrm{(P-3)} \mathrm{in} \mathrm{the} \mathrm{beach} \mathrm{Chorrillos} \mathrm{of}$ Huacho, conducted by the Laboratory "Minerals of laboratories S.R.L" to our request are presented in Tables 7, 8 and 9.

Table 7: physicochemical analysis of marine water

\begin{tabular}{|l|l|l|l|l|}
\hline Determination & \multirow{2}{*}{ Units } & Results & P-2 & P-3 \\
\cline { 3 - 5 } & & P-1 & 100 & 106 \\
\hline Alkalinity & $\mathrm{mg} / \mathrm{L}$ & 0.98 & 953 & 745 \\
\hline Hardness & $\mathrm{mg} / \mathrm{L}$ & 815 & 1089 & 103,5 \\
\hline Chlorides & $\mathrm{mg} / \mathrm{L}$ & 1024,1 & 159 & 148 \\
\hline Oils and greases & $\mathrm{mg} / \mathrm{L}$ & 136 & 7,65 & 7,66 \\
\hline pH & Standard & 7,51 & 17,5 & 17,7 \\
\hline Temperature & ${ }^{\circ} \mathrm{C}$ & 17,2 & 125 & 122 \\
\hline $\begin{array}{l}\text { Total suspended } \\
\text { solids }\end{array}$ & $\mathrm{mg} / \mathrm{L}$ & 164 & & \\
\hline Cyanide watt & $\mathrm{mg} / \mathrm{L}$ & $<0,004$ & $<0,004$ & $<0,004$ \\
\hline Total Cyanide & $\mathrm{mg} / \mathrm{L}$ & $<0,004$ & $<0,004$ & $<0,004$ \\
\hline
\end{tabular}

Table 8: bacteriological analysis of marine waters

\begin{tabular}{|l|l|l|l|l|}
\hline \multirow{2}{*}{ Determination } & \multirow{2}{*}{ Units } & \multicolumn{3}{|l|}{ Results } \\
\cline { 4 - 6 } & P-1 & P-2 & P-3 \\
\hline Total coliforms & Ufc & $<1$ & $<1$ & $<1$ \\
\hline Thermotolerant coliforms & Ufc & $<1$ & $<1$ & $<1$ \\
\hline Dissolved oxygen & $\mathrm{mg} / \mathrm{L}$ & 4,5 & 3,0 & 5,4 \\
\hline Biochemical Oxygen Demand & $\mathrm{mg} / \mathrm{L}$ & 18,3 & 13,4 & 13,9 \\
\hline
\end{tabular}

Napoleón JAUREGUI NONGRADOS, International Journal of Renewable Energy \& Biofuels, 
Table 9: metals analysis of marine waters

\begin{tabular}{|l|l|l|l|}
\hline \multirow{2}{*}{ Determination } & \multicolumn{3}{|l|}{ Results in (mg/L) } \\
\cline { 2 - 4 } & $\mathbf{P - 1}$ & $\mathbf{P - 2}$ & $\mathbf{P - 3}$ \\
\hline Lead & 0,11 & 0,05 & 0,02 \\
\hline Copper & 0,06 & 0,04 & 0,03 \\
\hline Zinc & $<0,01$ & $<0,01$ & $<0,01$ \\
\hline Iron & 0,95 & 0,31 & 0,18 \\
\hline Arsenic & $<0,01$ & $<0,01$ & $<0,01$ \\
\hline Cadmium & $<0,01$ & $<0,01$ & $<0,01$ \\
\hline Magnesium & 5,16 & 7,12 & 6,9 \\
\hline Nickel & 0,01 & 0,02 & $<0,01$ \\
\hline Manganese & 0,02 & 0,03 & $<0,01$ \\
\hline
\end{tabular}

\section{Effluent flow rates to the sea}

The effluent flows into the sea from the port of Huacho, measured on November 6, 2004, were as follows:

Table 10: effluent flows that end up in marine waters

\begin{tabular}{|c|c|c|}
\hline $\begin{array}{l}\text { Time of } \\
\text { measurement }\end{array}$ & Effluent & Flow $\left(m^{3} h^{-1}\right)$ \\
\hline $\begin{array}{l}\text { 10.00 A.M. } \\
\text { 10.30 A.M. } \\
\text { 11.00 A.M. }\end{array}$ & $\begin{array}{c}\text { 1.- Wetland drains: } \\
\text { - } \quad \text { Meander } 1 \\
\text { - } \quad \text { Meander } 2 \\
\text { - } \text { Meander } 3\end{array}$ & $\begin{array}{l}21,5 \\
11,3 \\
9,4\end{array}$ \\
\hline 11.30 A.M. & $\begin{array}{ll}2 .- & \text { Agricultural } \\
\text { Drain. } & \end{array}$ & 4413,0 \\
\hline 12.20 P.M. & $\begin{array}{l}\text { 3.- } \begin{array}{l}\text { EMAPA South } \\
\text { Collector }\end{array}\end{array}$ & 35,1 \\
\hline
\end{tabular}

\section{Negative landscape environment of the coastal waters}

Solid waste floating in the marine waters, such as plastics, cans, fish and dead birds, can be observed. Also, combustible oils are floating and their presence is characterized by the odor they emanate; likewise, feces and all types of solid waste, predominantly debris, can be seen on the coastal shore of this marine water. Fishing boats are anchored in the port in a disorderly manner and its two docks are not properly maintained.

\section{Measurement and evaluation of environmental impacts}

The environmental factors in the coastal waters of the port of Huacho that are being affected by pollutants are as follows:

\section{Physical-chemical components}

a) $\mathrm{Air}$

This component is affected by unpleasant odor gases from the fishing factories located in the area and from the gases emanating from the wastewater and solids that end up in the sea.

b) Geology

The erosion of the slopes of the ravine and Atalaya hill, due to the wind, is not taken into account and this causes the parapets that are on the edge of the ravine, which forms the boardwalk Roca, 
to end up deteriorating and fall, impacting the road that passes at the foot of the ravine, which to date, fortunately there has not been any accident for this reason.

c) Water

In this case, marine waters and wetland waters constitute them. These waters are affected by wastewater from the fishing industry, municipal, agricultural drainage and fishing boats; the reason is the observed presence of oily substances of hydrocarbons in these marine waters.

\section{Biological components}

\section{a) Fauna}

the alteration of the fauna is appreciable, observing marine birds feeding on waste, and others lying dead on the ground, as well as the species "very very" (emerita analoga), no longer exists, which in the past was very normal to find.

\section{b) Flora}

The flora present in the wetlands are seriously affected by the clearing that reduces their space and therefore the affectation of the fauna that depends on it. Moreover, the local government, far from avoiding this damage, is only leveling the clearings, reducing in some parts until the sands of the beach disappear.

\section{Socio-economic components}

\section{a) Cultural level}

The lifestyle of the population has been affected because they cannot make use of the marine waters for bathing, altering, for example, the custom of recreational use of this beach.

\section{b) Aesthetics}

The presence of solid waste and sewage affects the aesthetics of the port, as it alters its natural landscape.

c) Social

It especially affects the population because they have to visit other more distant beaches, leading to higher transportation costs and especially affects artisanal fishermen, since they cannot carry out their activities on this beach because it is closed to all activities.

\section{d) Health}

The health of the population is being affected, especially those who live in front of Chorrillos beach, separated by a ravine, where this ravine is plagued by a solid waste of all kinds and they are exposed to unpleasant gases from the fishing factories and sewage, which allow the development of vectors and consequently are infectious sources of potential disease transmission.

\section{f) Services}

The services provided by the port are limited, mainly used as a means of exporting fishmeal through its shipping dock. It is also used for anchoring fishing boats that allow the commercialization of various hydrobiological species; reason that in this area are located several restaurants that offer fish-based dishes.

\section{g) Civil works and green areas}

The civil works are done in the port consist of two docks, restaurants, housing and two fishing factories. There is also a small park with green areas.

The identification, measurement and evaluation of impacts of the coastal waters of the port of Huacho, where the Chorrillos beach of this port is located, are shown in Tables 11, 12 and 13 
Table № 11: identification and Measurement of Impacts of the coastal waters of the port of Huacho

\begin{tabular}{|c|c|c|c|c|c|c|c|c|}
\hline \multirow[t]{2}{*}{ № } & & & \multirow{2}{*}{\begin{tabular}{|l|} 
Type \\
$(+)(-)$ \\
\end{tabular}} & \multicolumn{5}{|l|}{ Magnitude } \\
\hline & \multicolumn{2}{|c|}{ Environmental Factors } & & Intensity & Persistence & Recoverability & Effects & Extension \\
\hline \multirow[t]{4}{*}{1} & Components & a) Air & - & Low & Permanent & Recoverable & Simple & Punctual \\
\hline & Physical- & b) Geology & - & Medium & Temporary & Recoverable & Simple & Partial \\
\hline & Chemical & c) Soil & - & High & Permanent & Recoverable & Cumulative & Total \\
\hline & & d) Water & - & High & Permanent & Recoverable & Synergistic & Total \\
\hline \multirow[t]{2}{*}{2} & Components & a) Fauna & - & Media & Permanent & Recoverable & Cumulative & Total \\
\hline & Biological & b) Flora & - & High & Permanent & Recoverable & Cumulative & Total \\
\hline \multirow[t]{6}{*}{3} & Components & a) Cultural Level & - & High & Permanent & Recoverable & Cumulative & Total \\
\hline & Socio- & b) Aesthetic & - & High & Permanent & Recoverable & Synergistic & Total \\
\hline & Economic & c) Social & - & High & Permanent & Recoverable & Cumulative & Partial \\
\hline & & d) Health & - & Medium & Permanent & Recoverable & Synergistic & Punctual \\
\hline & & e) Services & + & Low & Temporary & Recoverable & Simple & Partial \\
\hline & & $\begin{array}{l}\text { f) Civil works and green } \\
\text { areas }\end{array}$ & + & Low & Temporary & Recoverable & Simple & Partial \\
\hline
\end{tabular}


Table № 12: evaluation of the Magnitude of Impact of the coastal waters of the port of Huacho

\begin{tabular}{|c|c|c|c|c|c|c|c|c|c|c|c|}
\hline \multirow{2}{*}{\multicolumn{2}{|c|}{$\begin{array}{l}\text { Environmental } \\
\text { factors }\end{array}$}} & \multirow[t]{2}{*}{ Character } & \multirow{2}{*}{$\begin{array}{l}\text { Probab. of } \\
\text { Occurrence }\end{array}$} & \multicolumn{5}{|c|}{ Magnitude } & \multirow[b]{2}{*}{ Importance } & \multirow{2}{*}{$\begin{array}{l}\text { Impact } \\
\text { Total }\end{array}$} & \multirow{2}{*}{\begin{tabular}{|l} 
Total by \\
Aspects
\end{tabular}} \\
\hline & & & & Intensity & Persistence & Recoverability & Effects & Extension & & & \\
\hline \multirow{4}{*}{$\begin{array}{l}\text { A. } \\
\text { Aspects } \\
\text { Physical - } \\
\text { Chemical }\end{array}$} & a) Air & - & 0,50 & 0 & 2 & 1 & 0 & 0 & 2 & $-3,0$ & \\
\hline & b) Geology & - & 0,70 & 1 & 1 & 1 & 0 & 1 & 1 & $-2,8$ & \\
\hline & c) Soil & - & 1,00 & 2 & 2 & 1 & 1 & 2 & 8 & $-64,0$ & \\
\hline & d) Water & - & 1,00 & 2 & 2 & 1 & 2 & 2 & 10 & $-90,0$ & $-159,8$ \\
\hline \multirow{2}{*}{$\begin{array}{l}\text { B. Aspect } \\
\text { Biological }\end{array}$} & a) Fauna & - & 1,00 & 1 & 2 & 1 & 1 & 2 & 7 & $-49,0$ & \\
\hline & b) Flora & - & 1,00 & 2 & 2 & 1 & 1 & 2 & 9 & $-72,0$ & $-121,0$ \\
\hline \multirow{6}{*}{$\begin{array}{l}\text { C. } \\
\text { Aspects } \\
\text { Socio- } \\
\text { Economic }\end{array}$} & $\begin{array}{l}\text { a) Cultural } \\
\text { level }\end{array}$ & - & 1,00 & 2 & 2 & 1 & 1 & 2 & 6 & $-48,0$ & \\
\hline & \begin{tabular}{|l} 
b) \\
Aesthetic
\end{tabular} & - & 1,00 & 2 & 2 & 1 & 2 & 2 & 5 & $-45,0$ & \\
\hline & c) Social & - & 1,00 & 2 & 2 & 1 & 1 & 1 & 3 & $-21,0$ & \\
\hline & d) Health & - & 0,60 & 1 & 2 & 1 & 2 & 0 & 2 & $-7,2$ & \\
\hline & e) Services & + & 0,40 & 0 & 1 & 1 & 0 & 1 & 3 & $+3,6$ & \\
\hline & \begin{tabular}{|lr} 
f) & Civil \\
works & and \\
green areas
\end{tabular} & + & 0,40 & 0 & 1 & 1 & 0 & 1 & 3 & $+3,6$ & $-114,0$ \\
\hline & & & & & & & & & & TOTAL & $-394,8$ \\
\hline
\end{tabular}


Table № 13: rating of the Impact Assessment of the coastal waters of the port of Huacho

\begin{tabular}{|c|c|c|c|c|c|c|}
\hline \multirow{2}{*}{\multicolumn{2}{|c|}{ Environmental parameters }} & \multicolumn{5}{|l|}{ Rating scale } \\
\hline & & \multirow{2}{*}{$\begin{array}{l}\text { Not significant } \\
-X \\
\end{array}$} & \multirow[t]{2}{*}{ Slightly significant } & \multirow{2}{*}{\begin{tabular}{|l} 
Moderately \\
significant
\end{tabular}} & \multirow[t]{2}{*}{ Significant } & \multirow[t]{2}{*}{ Highly significant } \\
\hline \multirow{4}{*}{$\begin{array}{l}\text { Aspects } \\
\text { Physical - } \\
\text { Chemical }\end{array}$} & Air & & & & & \\
\hline & Geology & $-\mathrm{X}$ & & & & \\
\hline & Soil & & & & $-\mathrm{X}$ & \\
\hline & Water & & & & & $-\mathrm{X}$ \\
\hline \multicolumn{6}{|l|}{ Sub-Total } & $-\mathrm{X}$ \\
\hline \multirow{2}{*}{$\begin{array}{l}\text { Componentes } \\
\text { Biológicos }\end{array}$} & Fauna & & & $-X$ & & \\
\hline & Flora & & & & $-\mathrm{X}$ & \\
\hline \multicolumn{6}{|l|}{ Sub-Total } & $-\mathrm{X}$ \\
\hline \multirow{6}{*}{$\begin{array}{l}\text { Componentes } \\
\text { Socio - } \\
\text { Económicos }\end{array}$} & Cultural level & & & $-\mathrm{X}$ & & \\
\hline & Aesthetic & & & $-\mathrm{X}$ & & \\
\hline & Social & & $-\mathrm{X}$ & & & \\
\hline & \begin{tabular}{|l} 
Health \\
\end{tabular} & $-\mathrm{X}$ & & & & \\
\hline & \begin{tabular}{|l|} 
Services \\
\end{tabular} & $+\mathrm{X}$ & & & & \\
\hline & \begin{tabular}{|l} 
Civil works and \\
green areas
\end{tabular} & $+X$ & & & & \\
\hline \multicolumn{2}{|l|}{ Sub-Total } & & & & & $-\mathrm{X}$ \\
\hline \multicolumn{2}{|l|}{ Total } & & & & & $-\mathrm{X}$ \\
\hline
\end{tabular}

Napoleón JAUREGUI NONGRADOS, International Journal of Renewable Energy \& Biofuels,

DOI: $10.5171 / 2021.630428$ 


\section{Discussion of results and conclusions}

1.- From Table No. 02, the surveys carried out had higher participation of the male sex in $68.6 \%$ and according to Figure No. 01 , the average age of the respondent was 50 years old, which indicates that men of working age stay longer at home and have had the participation of people who know their environment.

Tables $\mathrm{N}^{\circ} 03,04$ and 06 show that $64.3 \%$ of the population feels affected by rodents and insects, this is corroborated by the observation made in the area, which indicates high contamination and damage to the health of the population, also $100 \%$ of the population assures that the fishing fleets dump their waste into the sea and $61.4 \%$ are fully convinced that the coastal waters are contaminated by the activities of the factories, and $99.9 \%$ accept that they are responsible, stating that they are witnesses that the neighbors throw garbage into the creek of the port; $100 \%$ affirm that they are not organized to prevent the pollution of coastal waters, and $100 \%$ affirm that these waters are polluted. This explains why $76.4 \%$ indicate a lack of environmental education and lack of control by the regulatory agency. However, only $37.1 \%$ accept that marine waters have caused them health problems, which infers that they are not aware of the potential risk to which they are exposed and the magnitude of the damage they are enduring.

Table No. 05 has an important indicator since $88.3 \%$ state that they do not fish in this port because of the scarcity of marine resources and $64.3 \%$ do not use them, despite the fact that $85.7 \%$ of the population is dedicated to fishing. This means that the socio-economic and cultural impact also affects the economies and the standard of living of the population, which indicates a little opportunity for development in the area.

From Table No. 06, it can be seen that despite the limitations of the population, $12.9 \%$ are willing to participate in the environmental recovery of their marine waters and $92.1 \%$ are willing to pay for their recovery, which shows that there is identification and environmental sensitivity; they only lack motivation and environmental education to ensure a preserved environment, since $45 \%$ plan to protest to prevent the destruction of their port landscape; this is a potential conflict that the authorities should avoid for the welfare of their population.

2.- The determination of the quality of the waters of the beach Chorrillos of Huacho was made only in comparison with the Class IV use waters established in the General Water Law, since the others are for drinking and agricultural use, waters that are not being evaluated in this research work. From the laboratory analysis, regarding the physicochemical analysis of these marine waters, in contrast to the permissible limits of the General Water Law, it cannot be measured because this law does not contemplate the parameters performed, except for cyanide, which is not a limit for Class IV waters. For all the cases in Table 07, values lower than $0.004 \mathrm{mg} . \mathrm{L}^{-1}$ of cyanide were obtained, which indicates that these values comply with the permissible limits of the General Water Law and even with the WHO standard that regulates $0.05 \mathrm{mg} . \mathrm{L}^{-1}$. Therefore, the concentration of cyanide in these waters is acceptable.

From the bacteriological analyses obtained in Table No. 08, total coliforms and thermotolerant coliforms were less than 1 Ufc, which shows indicators that comply with the General Water Law and the WHO standard, but not with the APM, which regulates 200 microorganisms / $100 \mathrm{~mL}$. However, it should be noted that the shores of the marine waters have the physical presence of fecal solids, which shows a high degree of resilience of these marine waters and therefore, they are not suitable for recreation according to the APM.

As for BOD5,20 an average value of 15.2 $\mathrm{mgL}^{-1}$ was obtained, with a concentration of $18.3 \mathrm{mgL}^{-1}$ at $500 \mathrm{~m}$ sea out, suggesting that marine waters are contaminated by organic compounds with high microbial 
oxidation in relation to the General Water Law and PAHO standards.

The dissolved oxygen determined complies with the parameters of the law, in which an average of $4.3 \mathrm{mg} . \mathrm{L}^{-1}$ was obtained, being more critical at $250 \mathrm{~m}$ sea out where 3 mg. $\mathrm{L}^{-1}$ was obtained. However, these same results in comparison with WHO and PAHO standards show that these waters are very polluted at $250 \mathrm{~m}$ sea out being so close to the bank, indicating that the use of these waters for recreation with bodily contact is very risky. Also, taking as a reference Davis and Masten, who argue that "when dissolved oxygen is reduced from 5 to $4 \mathrm{mg} . \mathrm{L}^{-1}$, most of the sportfishing will have disappeared" and based on our results, the impact on the biomass of these waters is demonstrated, the reason that in Table No. 04, the inhabitant affirms the little existence of the marine resource.

Regarding the analysis of metals in these waters in Table № 09, in contrast to the General Water Law, the Lead obtained on average is $0.06 \mathrm{mg}$. $\mathrm{L}^{-1}$, this shows high concentration for classes $\mathrm{V}$ and VI and it is not possible to evaluate for class IV, since the law does not apply it, which means that it accepts any concentration for recreational use of body contact, being more contaminated at $500 \mathrm{~m}$ sea out where $0.11 \mathrm{mg} . \mathrm{L}^{-1}$ was obtained and these same results in comparison to the WHO, shows high contamination, since, the WHO accepts up to $0.01 \mathrm{mg} . \mathrm{L}^{-1}$.

Regarding copper, cadmium and nickel; the average results in that order are: $0.043 ; 0.001,0.015$ mg.L-1; which show high concentration in comparison to classes III, V and VI, being impossible to evaluate class IV since the General Water Law does not apply and these same values in relation to the WHO are accepted. In this sense, these metals in these waters are not a problem swimming.

The results for iron $(0.18,0.31$ and 0.95 $\mathrm{mg} / \mathrm{L})$, arsenic (<0.01 mg/L), magnesium $(6.9,7.12$ and $5.16 \mathrm{mg} / \mathrm{L})$, zinc $(<0.01)$, and manganese $(<0.01,0.03$ and 0.02 $\mathrm{mg} / \mathrm{L}$ ) are not applicable to the General Water Law and, in relation to the WHO and
PAHO, are within their limits. Therefore, there is no contamination of marine waters by these elements. Similarly, the law does not apply the results obtained for chlorides (103.5, 1089 and $1024.1 \mathrm{mg} / \mathrm{L})$, oils and fats $(148,159$ and $136 \mathrm{mg} / \mathrm{L})$, and total suspended solids (122, 125 and $164 \mathrm{mg} / \mathrm{L})$ and, compared to WHO and PAHO, all of them are above their limits. This shows the high contamination of marine waters by these substances.

The $\mathrm{pH}$ (7.66, 7.65 and 7.51) is only comparable to that of the PAHO, showing that the seawater is excellent, and the temperature (17.7, 17.5 and $17.2{ }^{\circ} \mathrm{C}$ ), according to Table 7 , is normal for Peruvian coastal waters.

The environmental damage demonstrated beach at Chorrillos of Huacho is corroborated by other works carried out previously, such as the General Directorate of Environmental Health, who in coordination with the Provincial Municipality of Huaura-Huacho, have closed this beach, for finding it with limits of thermotolerant coliforms that exceed the standards and also because its sands are of very poor quality, having "garbage" all over the beach.

Similarly, Orozco et al. (1995) demonstrated that the ecosystems of the bay of the port of Huacho support a pollution load above the maximum permissible limits. In addition, the effects of pollution in this bay were studied by Sánchez et al. (1996), who demonstrated that macrozoobenthos have disappeared from their natural habitat. And the results of these works are reaffirmed by Evangelista (2002), who shows that pollution persists in the bay of Huacho, especially in its port; being this work subsequent to those mentioned, it has been found that the biochemical oxygen demand (BOD5,20) has increased by approximately 50\%, which shows that environmental damage not only persists but has increased in the beach Chorrillos of Huacho.

3.- The wastewater flows shown in Table 10 , the largest volume flow is from the 
agricultural drain followed by the South Collector, which is domestic wastewater. It was not possible to measure the main effluents of the fishing plants, since their pipes end in the agricultural drain inside the factories and since there was no access to them, it was not possible to make the respective measurements. The flow of the agricultural drain is responsible for the sandblasting of the port, while the flow of the South Collector is small and its load may very well be dissipated by marine currents.

4.- Table 13 is the result of the analysis of Tables 11 and 12, where the identification, assessment and evaluation of impacts with respect to the port of Huacho and its Chorrillos beach ware performed and obtained non-significant impacts for the physical-chemical components: air and geology; significant for the soil. As for the biological component, highly significant; moderately significant socio-economic components in terms of cultural and aesthetic level, slightly in the social and not significant with respect to health, based these assessments based on field observation and the results of the survey, since it is not possible to take more criteria, since there are no statistical records in the files of the competent institutions in the area, in terms of damage to health, economic and externalities in general due to pollution in the coastal waters of the port of Huacho. In this sense, the socio-economic impacts are not very affected. Therefore, it is demonstrated that the coastal waters of the port of Huacho are greatly affected by pollution and the evaluated characteristics of it, shows that environmentally Chorrillos beach is recoverable, requiring environmental management for recovery and conservation by the competent authority such as the Regional Government, local and the National Environmental Council, otherwise it will not contribute to the sustainable development of this port huachano, this is clear from Table 5 , where 92, $1 \%$ of the population considers this port as a tourist resource, with a bad quality value at $60 \%$, which shows an opportunity to turn it into a tourist resort, because it has all the resources to be exploited and if not, it would be a malignant environment, as a highly infectious focus that can trigger a series of diseases, even unknown, as the recent ones appeared at international level, such is the case of the avian flu, which is deadly and very difficult to immunize every human being because of its constant mutation. What urges the need to recover this space not only for the development of the people of Huacho but for the welfare of humanity and our planet.

\section{Acknowledgement}

The article for publication in IBIMA was funded by the Universidad Privada del Norte, and all the research was financed by the researcher's own resources.

\section{References}

- Aznar, P. (1998), La educación ambiental en la sociedad global, Universidad de Valencia, Valencia.

- Canter, L. (1999), Manual de evaluación de impacto ambiental, Mc Graw Hill, Colombia.

- Collazos, J. (2004), El estudio de mercado en los proyectos de inversión, Editorial San Marcos, Lima.

- Consejo Nacional del Ambiente y Banco Interamericano de Desarrollo. (2000), Marco estructural de gestión ambiental, Consejo Nacional del Ambiente, Perú.

- Conesa, V. (1997), Guía metodológica para la evaluación del impacto ambiental, Mundi-Prensa, Spain.

- Cooper, C. y Zedler, P. (1980), Ecological assessment for regional development, Environmental management, 10:285-296.

- Davis, M. y Masten, S. (2005), Ingeniería y ciencias ambientales, Mc Graw Hill, Mexico.

- Dirección General de Salud Ambiental. (1999), Playas. Salud ambiental, 12 (4), 60.

- $\quad$ Evangelista, V. (2002), Impacto de los vertimientos industriales $y$ domésticos en la calidad de las aguas del puerto del Huacho, Universidad Nacional de Trujillo, Trujillo. 
- Helmer, R.y Hespanhol, I. (1999), Control de la contaminación del agua, Panamericano de Ingeniería Sanitaria y Ciencias del Ambiente, Lima.

- Kiely, G. (1999), Ingeniería ambiental: fundamentos, entornos, tecnologías y sistemas de gestión, Mc Graw Hill, Madrid.

- Jáuregui, N. (2003), Propuesta de uso ecoturístico de la playa Chorrillos de Huacho, Universidad Nacional José Faustino Sánchez Carrión, Huacho.

- Metcalf, E. (1977). Tratamiento y depuración de las aguas residuales. Labor S.A., Spain.

- Orozco, R.; Córdova, J. y Morrón, 0. (1997), Evaluación de efectos de la contaminación sobre el ecosistema marino de Huacho y Carquín en 1995, Informe Progresivo del Instituto del Mar del Perú, 53: 82.

- Potter, M. y Wiggert D. (1998), Mecánica de fluidos, Prentice Hall, Mexico.

- Sánchez, G. y Alvarado, D. (1996), Evaluación de los efectos de la contaminación en el macrobentos de la bahía Carquín, Huacho 1990-1991, Informe Progresivo del Instituto del Mar del Perú, 48: 62.

- Tchobanoglous, G.,Theisen, H. y Vigil, S. (1994), Gestión integral de residuos sólidos. Mc Graw Hill, Spain.

- Tyler, M. (2002), Introducción a la ciencia ambiental, Thomson, Spain.

- Winkler, M. (1999), Tratamiento biológico de aguas de desecho. Limusa S.A., Mexico.

\section{NOTE}

Attached is the assay report of the Laboratory "Minerales de laboratorios S.R.L.-Minlab", who performed the analyses at our request for the present investigation, the results of which are presented below:
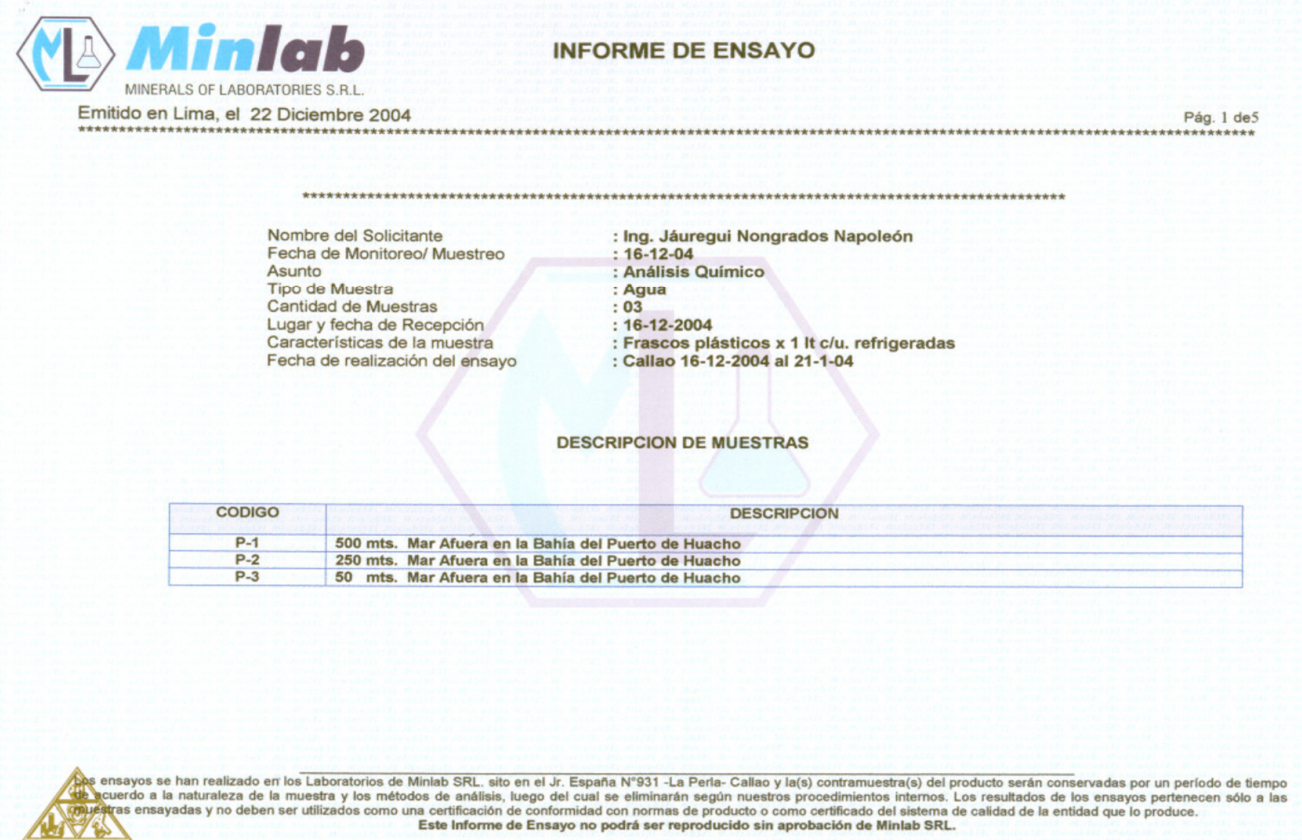


\section{(ML) Minlab}

INFORME DE ENSAYO
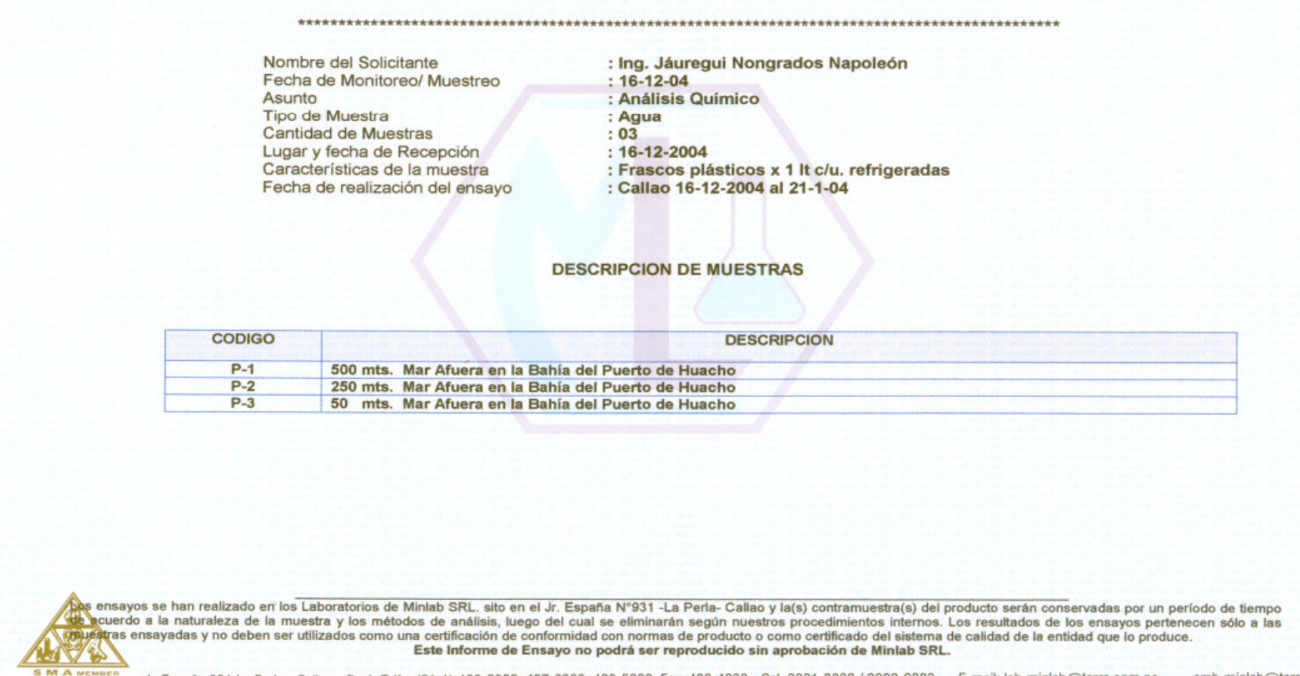

Jr. Espana 931 La Perla - Calla - Peru Telfs. (51-1) 420-5955 457-6389 420-5280 Faxc 420-4933 - Cel. 9901-3002/9902-6883 E-mal: lab-minlab@terra.com.pe amb-minlab@terra.com.pe

\section{METODOS DE ENSAYO}

\begin{tabular}{|c|c|}
\hline DETERMINACION & METODOLOGIA \\
\hline Determinación de Cianuro Watt & SMEWW. APHA.AWWA.WEF. 20thEdition. 1999.Part 4500-CN B. Método Colorimétrico. \\
\hline Determinación de Cianuro Total & SMEWW. APHA. AWWA.WEF. 20thEdition. 1999. Part 4500-CN B. Método Colorimétrico. \\
\hline Determinación de Cadmio & SMEWW. APHA.AWWA.WEF. 20thEdition. 1999.Part 31118. Metals by Flame Atomic Absorption Spectrometry. Direct Air Acetylene Flame Method \\
\hline Determinación de Plomo & SMEWW. APHA.AWWA.WEF. 20thEdition.1999.Part 3111B. Metals by Flame Atomic Absorption Spectrometry. Direct Air Acetylene Flame Method \\
\hline Determinación de Cobre & SMEWW. APHA.AWWA.WEF. 20thedition. 1999. Part 3111B. Metals by Flame Atomic Absorption Spectrometry. Direct Air Acetylene Flame Method \\
\hline Determinación de Zinc & SMEWW. APHA AWWA.WEF. 20th Edition. 1909.Part 3111B. Motals by Flame Atomic Abeorption Spectromety. Direot Air Aootylene Flame Mothod \\
\hline Determinación de Hierro & SMEWW. APHA.AWWA.WEF. 20thEdition.1999. Part 3111B. Metals by Flame Atomic Absorption Spectrometry. Direct Air Acetylene Flame Method \\
\hline Determinación de Arsénico & Test Arsénico (sensible) test colorimettico. \\
\hline Determinación de Magnesio & SMEWW. APHA.AWWA.WEF. 20thedition.1999.Part 3111B. Metals by Flame Atomic Absorption Spectrometry. Direct Air Acetylene Flame Method \\
\hline Determinación de Manganeso & SMEWW. APHA.AWWA.WEF. 20thEdition.1999. Part 31118. Metals by Flame Atomic Absorption Spectrometry. Direct Air Acetylene Flame Method \\
\hline Determinación de Niquel & SMEWW. APHA.AWWA.WEF. 20thEdition. 1999. Part 31118. Metals by Flame Atomic Absorption Spectrometry. Direct Air Acetylene Flame Method \\
\hline
\end{tabular}

METODOS DE ENSAYO

\begin{tabular}{|l|l|}
\hline \multicolumn{1}{|c|}{ DETERMINACION } & EPA 1664 Approved for NPDES (Revisión A pag 1-23) \\
\hline Determinación de Aceites y Grasas & METODOLOGIA \\
\hline Determinación de Cloruros & EPA 325.3 Approved for NPDES (Editorial Rev 1982) \\
\hline Determinación de Alcaliniad Total & SM 2320-8 Ed 20 th, pag 2-27 \\
\hline Determinación de Dureza Total & EPA 215.2 Appoved for NPDES (Editorial Rev 1978) \\
\hline Determinación de Oxigeno Disuelto & EPA 360.2 Approved for NPDES (Editorial Rev 1978) \\
\hline Determinación de pH & EPA 150.1 (Editorial Rev 1978) \\
\hline Determinación de Temperatura & EPA 170.1 Approved for NPDES (Elitorial Rev 1974) \\
\hline Determinación de TSS & EPA 160.3 Approved for NPDES (lssued 1971) \\
\hline Determinación de Nitratos & EPA 354.1 Approved for NPDES (lssued 1971) \\
\hline
\end{tabular}

Aos ensayos se han realizado en los Laboratorios de Minlab SRL. sito en el Jr. Espana N"931 - La Peria- Callao y la(s) contramuestra(s) del producto serán conservadas por un periodo de tempo

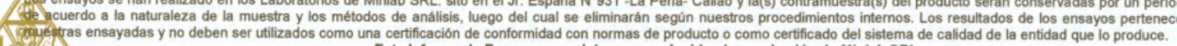




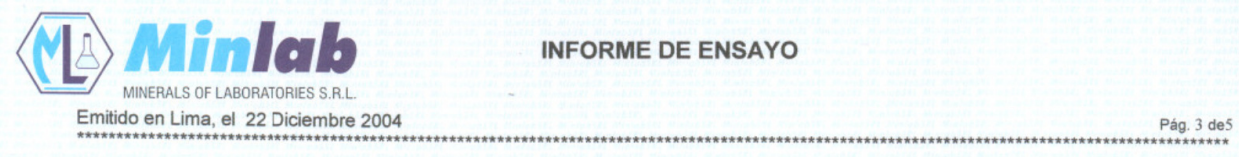

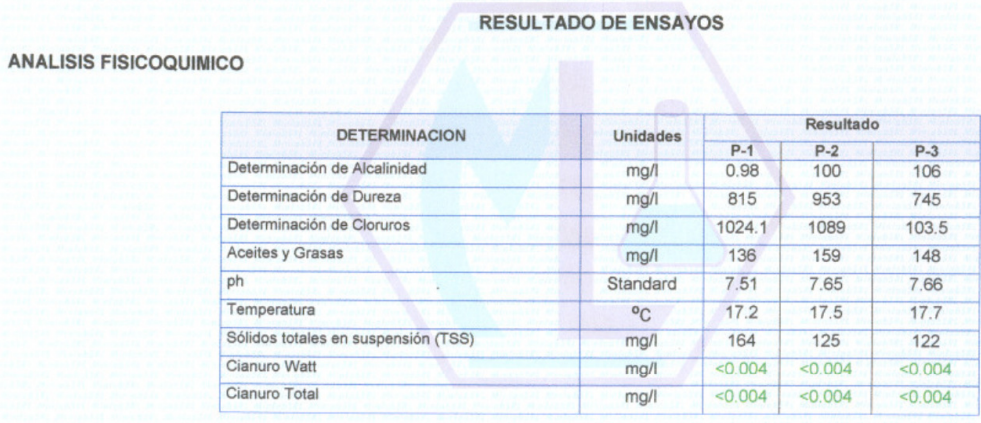

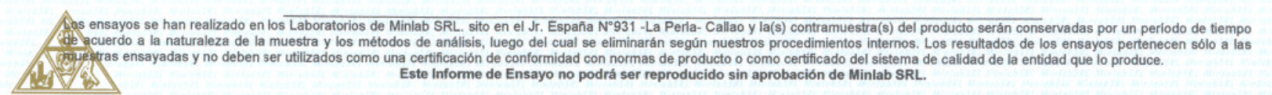

Jr. España 931 La Perla - Calla - Peni Tells. (51-1) 420-5955 457-6389 420-5280 Fax: 420-4933 - Cel. 9901-3002/9902-6883 E-mail: lab-minlab@terra.com.pe amb-minlab@terra.com.pe

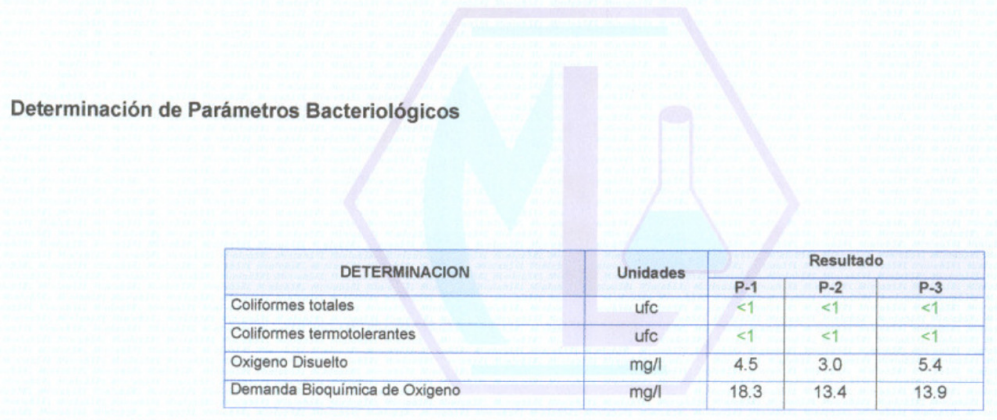

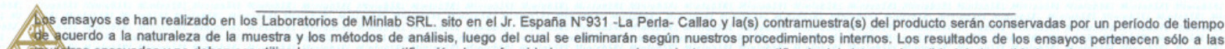
Goutestras ensayadas y no deben ser utilizados como una certificación de conformidad con normas de producto o como certificado del sistema de calidiad de la entidad que lo produce.

Jr. España 931 La Perla - Callao - Perú Telits. (51-1) 420-5955 457-6389 420-5280 Fax. 420-4933 - Cel. 9901-3002/9902-6883 E-mail: lab-minlab@terra.com.pe amb-minlab@terra.com.pe

Napoleón JAUREGUI NONGRADOS, International Journal of Renewable Energy \& Biofuels, DOI: $10.5171 / 2021.630428$ 


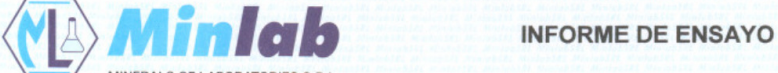

Metales Totales

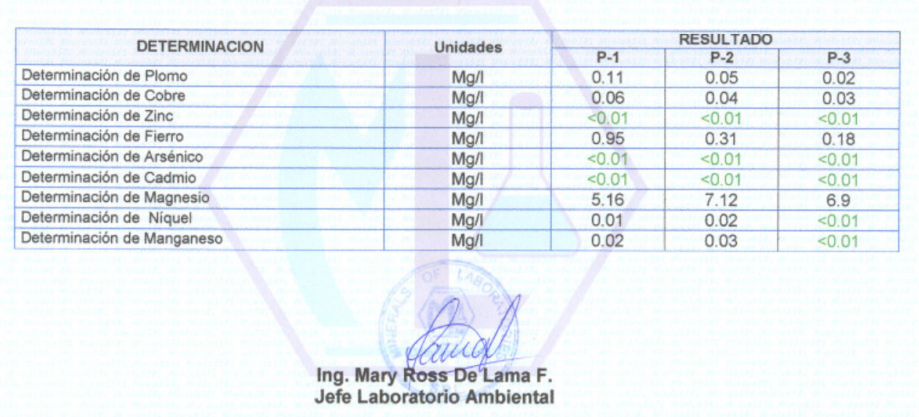

Jefe Laboratorio Ambient.

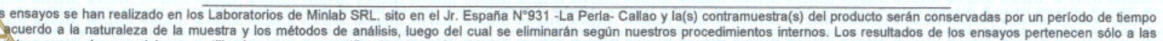

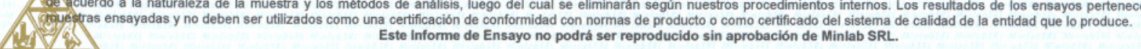

